\title{
The "Appearance of Innocence"
}

\section{Watching the Soviet Sixties Through Children's Animation}

\author{
AUTHOR: Rebecca Silver \\ EDITED BY: Malika Navruzova, Esti Azizi, and Marisa Coulton
}

The animated cartoon Redhead, Redhead, Freckle-face begins with an innocent story-line: a young boy ridiculed for having red hair. ${ }^{1}$ By the end, the sun has turned the whole world red to the delight of the boy. By using Communist imagery, the joyful ending of this children's cartoon clandestinely signals the power of the Soviet state through the spread of Communism. After showing this film to the class, my Russian language professor looked at us with a broad smile and said, "Wasn't that cute? I used to watch that as a child." These subtle references to the communist ideology of the Soviet Union, often found within seemingly innocent childhood entertainment, reveal the pervasive and disturbing nature of Soviet propaganda. Propaganda pieces were often used by the Soviet Union to maintain stability and control, particularly during the years of uncertainty following Stalin's death and Khrushchev's Secret Speech denouncing Stalin's legacy in $1956 .{ }^{2}$ The Khrushchev years also marked an uneasy openness and shift away from the Stalin state-induced fear toward a sixties peace movement, Soviet style. Unsurprisingly, animated children's programming produced during the Soviet sixties reflect broader socio-political trends indicative of the time and spirit of that era. Chief among these trends are the concepts of socialist internationalism, competition and patronage both within and outside of the socialist system, a rise in Khrushchev-inspired consumerism, and an increase in travel and tourism. ${ }^{3}$

Two animated children's shows, Read this and Travel to Paris and China (hereafter referred to as Read this and Travel) and The Three Fat Men, are prime exemplars of this unique sixties form of promotion of Soviet ideals through representation. These cartoons provide a rich platform for discussion as they share similarities regardless of their differences in styles and content. Many cartoons produced throughout the sixties in the Soviet Union sent different messages and signals to those who consumed them. It is, however, the layers of overlapping similarities and multiple divergences between these two films which provides informed conclusions on the sociopolitical atmosphere in the Soviet Union at the time of their production. Through an analysis of Read this and Travel and The Three Fat Men, this paper will argue that Khrushchev's policies influenced the uniquely "Soviet" way the sixties were represented in the Soviet Union. Additionally, cartoons can be considered representative of an intergenerational form of propaganda produced by a centralized agency. For these reasons, they may inform the viewer about policy decisions and the spirit of the decade.

To support the above argument, this paper will first contextualize the culture during the Khrushchev era, as well as Khrushchev's political aims. Next, it will examine the reception and audience of animated cartoons: who was watching them and how they may have been interpreted. Finally, this paper will use both Read this and Travel and The Three Fat Men as case studies to examine trends in travel and tourism, socialist internationalism, a rise in consumerism, and competition and patronage both within and outside of the socialist system.

To determine Khrushchev's effect on Soviet society in the sixties, this paper will enter into a dialogue with scholarship concerning the import 
of Soviet cartoons. Many scholars, most notably Natalie Kononenko, examine these media devices in relation to folklore inspirations ${ }^{4}$ Another scholar utilizing the folkloric trope is Brigit Beumers. She suggests that Soviet animation should not be considered propaganda as the genre was less affected by ideology in comparison to other forms of Soviet art. ${ }^{5}$ In response, Kononenko argues that the widely held belief that children's entertainment was innocent and beyond ideology is naive. ${ }^{6}$ In Kononenko's opinion, it is the "appearance of innocence that allows creators of animated films $[\ldots]$ to exert a powerful influence on society." ${ }^{\prime \prime}$ This paper will build on Kononenko's interpretation of animated films, which proposes the media source did influence Soviet society in the sixties and may indeed be considered a subtle, yet powerful, form of socialist propaganda.

Laura Pontieri is another scholar who contends that Soviet animation was not only produced for a youth audience. ${ }^{8}$ Pontieri focuses on the sixties, but suggests that cartoons produced during this period were created with an adult audience in mind, and with an underlying message directed at a mature audience. ${ }^{9}$ To support her theory, she analyzes cartoons intended for a youth audience, examining the language and images for incongruities in style and substance. ${ }^{10}$

In light of these scholarly works, this essay views animation as representative of trends in Soviet culture and as direct creations of Khrushchev's policies during the sixties. This contention is supported by the manner in which these cartoons were produced. Soyuzmultfilm, the Soviet production studio creating these cartoons, was a bureaucratic organ in a centralized state. Its mandate was to produce material consistent with the party line and state beliefs. ${ }^{11}$ Such animation reflected the state-approved vision that officials wanted the citizenry to believe, no matter the age or generation. ${ }^{12}$ Similar to Pontieri's research, this paper uses the 1960 s as a focal point. However, this paper will use cartoons as the lens through which to view the 1960s and through which
Khrushchev's policies are animated. This analysis makes arguments about the era itself rather than on the specific purpose and use of the cartoons.

The era of Khrushchev was characterized by many changes in Soviet society, now known by historians as The Thaw. ${ }^{13}$ This period was marked by the eradication of the repressive policies associated with Stalin, the release of prisoners from camps across the Soviet Union, and the liberalization of the press and arts. ${ }^{14} \mathrm{~A}$ new cultural shift away from Stalin-era collectivization and toward individualization resulted in several "thaw" policies such as increased consumerism and the privatization or westernization of living spaces. ${ }^{15}$ Significantly, these "thaws" in Soviet policy were uneven and erratic, often followed by destabilizing "freezes."16 The limited opening of the Soviet Union exposed many Soviet individuals to the spirit of the sixties through contact with the West, yet due to the "thaw-freeze" dichotomy, these westernized ideals were expressed in a uniquely Soviet way.

Khrushchev's foreign policy also reflected the internal changes occurring in Soviet society. His global approach was relatively peaceful compared to Stalin's aggressive stance. Although Khrushchev firmly believed in socialism's eventual economic victory over capitalism, he also believed in and encouraged peaceful economic competition with Western countries. ${ }^{17}$ Underlying this policy was Khrushchev's view that war with capitalist countries was not inevitable nor was it desirable. ${ }^{18}$ On the contrary, he was convinced that a major world war could be avoided through a peaceful, world transition to socialism. ${ }^{19}$ As a result, he supported non-violent, parliamentary transitions to socialism in other countries, rather than destabilizing revolutionary approaches. ${ }^{20}$ Instead of fearing the West, Khrushchev welcomed the comparison between capitalism and socialism, encouraging transnationalism and an easing of travel restrictions to Western countries. ${ }^{21}$ These policies were consistent with the general spirit of the sixties as envisioned in the West. 
Culturally, Khrushchev denounced Stalin's ideologies, which initially created a sense of dislocation in the Soviet Union. Instead of leaning on the recent past for inspiration, Khrushchev revived Leninist norms and embraced the spirit of the Russian Revolution. ${ }^{22}$ This connection with the distant past was taken up by the arts in a search to find acceptable stories and morals to teach to the next generation. ${ }^{23}$ The perfect container for these narratives and parables was children's literature.

Children's literature underwent significant modernization at the time of this socio-political shift in Soviet culture. New technological advances literally brought literature to life through the televised medium. As a result of these new technological advances and Western sixties consumerism, Soviet television ownership increased. ${ }^{24}$ By the 1970s, Soviet television would be the leading source for propaganda as Soviet families fully embraced the new technology. ${ }^{25}$ Further, the advent of consumerism took on a decidedly different aspect in the Soviet Union due to the nature of the economy and culture infused by the communist ideology. ${ }^{26}$ Television programming for children was one of the state-approved communication devices perfected in the sixties, which was encouraged by the predilection for television. ${ }^{27}$ It can therefore be assumed that the influence of cartoons increased exponentially with the increase in television ownership as an expression of the Soviet-style consumerism of the sixties.

A possible reason for the dual growth in consumerism and television ownership was an increase in the privatization of living spaces. Between 1953 and 1970, approximately 38 million families moved into new single-family apartments. ${ }^{28}$ This "individualization" of families resulted in the ability of intergenerational enjoyment of television programs from the comfort of their new homes. ${ }^{29}$ The increase in television-based entertainment consumption throughout the Soviet Union is reflected in the statistics of the time. In 1960, there were approximately 44 individuals per television set in the USSR. This number shifted to approximately
7 individuals per television set within the decade. ${ }^{30}$ In 1960, 5 million households in the Russian Soviet Republic had access to television services; this number increased to 10.5 million by 1963 , and would reach 25 million by $1970 .{ }^{31}$

The increase in production and consumption of cartoons which can be attributed to the rise in television ownership had ideological ramifications. In the 1950s and early 1960s, there were some collective areas to watch television, such as clubs, museums, and for youth, children's homes. ${ }^{32}$ However, with Khrushchev's building scheme and the increase in private apartments, children watched cartoons with their families, instead of in a collective and controlled setting. Khrushchev's policies and the generally freer spirit of the 1960s allowed for an increase in individual choice, especially in the realm of domestic and consumer goods. The interpretation of cartoons became less predictable and more difficult for the state to monitor, control, and dictate as a result of this sixties-style freedom. ${ }^{33}$ Not only did this permit more individualistic interpretation of cartoons, but it also allowed the individual a chance to escape from the message of the cartoon at will and "turnoff" when desired. ${ }^{34}$

The content of cartoons also reflected a marked change after Stalin's death. The party, the press, and the public demanded more from the genre than merely mindless children's entertainment. ${ }^{35}$ This change in modes of reception is examined in depth by Slavic Languages and Literatures historian David MacFadyen. MacFadyen suggests that after Stalin's death, the production of cartoons aimed to answer public demand and present the public with what they desired to see. ${ }^{36}$ This public demand wanted more satirical films and "foreign or exotic screenplays." 37 These adult-oriented demands support Pontieri's argument that cartoons at this time were not only pandering to younger audiences. However, within the more adult-oriented goal of unique storylines was the state's desire to display the "fantastic," or story-lines more attuned to the fantasy genre and less realistic in nature. ${ }^{38}$ 
This corresponded to a movement away from the "hyper-accuracy" of the Stalinist years. ${ }^{39}$ In order to align oneself with the new party goals, one would have to present "either emotion, expression, and a spectacle or an homage to Maiakovskii's [sic] lost art of the revolutionary poster." 40 These feelings of emotion, as well as the connection to Mayakovsky, is seen in the two cartoons discussed in this paper. The Three Fat Men itself is a representation of the Revolution, while Read this and Travel is based on a poem written by Vladimir Mayakovsky, a preRevolutionary Soviet literary artist and actor. Both of the texts used as inspiration for these cartoons were originally children's literature. The aspiration for animation to appeal to emotions may be interpreted as aligning with a more youth-oriented goal. Thus, Soyuzmultfilm may have attempted to appeal to youth through content, while the genre itself attempted to appeal to adult viewers.

Many of these cartoons, such as Read this and Travel and The Three Fat Men, were produced by Soyuzmultfilm, which was originally established in 1936 under the name Soyuzdetmultfilm. ${ }^{41}$ "Det" is an abbreviation for the Russian word detskii, meaning children, and therefore the eventual removal of this abbreviation further supports Pontieri's argument that Soyuzmultfilm produced cartoons for a variety of audiences. ${ }^{42}$ This centralized agency was created to strengthen state control over the production of films. ${ }^{43}$ With the creation of this centralized group, individual artists came under the direct control of the state and had less artistic license. ${ }^{44}$ The Brumberg sisters, the directors of The Three Fat Men, said to be "old enough to have studied with Mayakovsky," were extremely active in Soyuzmultfilm, directing more than forty films in their fifty years at the studio. ${ }^{45}$ Directors at Soyuzmultfilm, such as the Brumbergs, had to be aware that "cartoons, for all their fun, were in harmony with the methods of constant revolution." 46 Although the production of children's cartoons appeared to be an innocent occupation, they needed to conform to the ideology of the time, as was true for all culture in the Soviet Union.
Both Read this and Travel, produced in 1960, and The Three Fat Men, produced in 1963, provide insights into the Soviet Union in the sixties. Both films are based on texts from the 1920s: Read this and Travel is based on a poem written by Mayakovsky in 1927 while The Three Fat Men is based on a short story written by Yuri Olesha in 1924. These two writers may be representative of the liberalization of The Thaw, as both opposed Socialist Realist policies. Socialist Realism was the official methodology of Soviet literature, introduced at the first Soviet Writers' Conference in $1934 .{ }^{47}$ The principles of Socialist Realism required that the writer or artist depict reality as "historically accurate," while educating the people ideologically through the representation. ${ }^{48}$ Socialist Realism was used as propaganda to depict the utopia that the state was working towards and was fundamental in the process of socialist state formation. ${ }^{49}$ Both Mayakovsky and Olesha's opposition to Socialist Realism, and their subsequent use in sixties cartoons, may represent a shift away from this form of art towards a more liberal literary representation seen throughout the Soviet Union during the sixties.

Vladimir Mayakovsky was a literary figure who has become closely linked with the Russian revolution. As a writer, Mayakovsky was an extremely vocal supporter of revolutionary ideals and wrote many propagandistic verses, which were meant to support and reinforce the spirit of the revolution. ${ }^{50}$ Although Mayakovsky committed suicide in 1930 as a response to Socialist Realist policies, his works remain representative of the revolution. ${ }^{51}$ This violent response to Socialist Realism may be representative of Mayakovsky's intense rejection of this form of art, and the return to Mayakovsky as an acceptable inspiration for state sponsored propaganda in the 1960s may be demonstrative of a movement away from Socialist Realism.

Read this and Travel is a film encouraging communist children to travel around the world, spreading positive ideals and values, such as peace, friendship, and solidarity. Films such as 
these, attempting to educate children on ideal socialist principles, were common during the time of The Thaw. ${ }^{52}$ Although Read this and Travel appears to be advocating for peace and harmony, it is unclear which ideology will provide the setting for this peaceful world. The film ends with children joining hands around the globe with a dove in the centre, signifying a world of peace, but the ideology that this world will be formed through can be derived by inference only. ${ }^{53}$ This portion of the cartoon may be connected to the global revolutions during the sixties, which caused both the United States and USSR to scramble for patronage. It is also reflective of the increase in tourism during the sixties. In this era, the Soviet Union used transnational contact as a fundamental part of the struggle for international hegemony that was central to the Cold War. ${ }^{54}$ This transnational contact consisted of cultural, political, and technological exchange, both with Soviet satellite states and with the West. ${ }^{55}$ In the cartoon, the children are shown spreading socialist ideals, which eventually supplant other "inferior" ideologies. Through transnational contact, the positive ideology of socialism is spread across the globe and creates a world that is united through brotherly love, harmony, and most importantly, socialism. This also ties into the concept of socialist internationalism, which was linked with the desire of the Soviet Union to appear supportive of newly established socialist states. ${ }^{56}$ This image of socialist internationalism is more clearly shown in the interactions between the travelling children and their Chinese "brothers" that will be discussed below.

The portrayal of China as a "brother" of the Soviet Union may be representative of the concept of Soviet internationalism, which was espoused in the sixties, although the Sino-Soviet Split was fast approaching. The industrial landscape of China is glorified and praised, compared to the landscape of America, which is represented as negative and cacophonous. ${ }^{57}$ Furthermore, Chinese children are greeted as "brothers" by the traveling Russian youth. ${ }^{58}$ This representation was being received amid a turbulent, but not yet critical, political atmosphere. In 1960, the year of release of Read this and Travel, tensions had risen between the two countries over political decisions made by Mao, resulting in the withdrawal of Russian specialists from China. ${ }^{59}$ However, the relations between the Soviet Union and China remained smooth until the end of $1962 .{ }^{60}$ Therefore, it would be logical for the cartoon to downplay any tension between the two countries and focus on the concept of internationalism, or the idea of socialist "friendship" and interconnectedness. ${ }^{61}$ In the cartoon, just as in policy, the Soviet Union attempted to play the role of an elderly brother, guiding other socialist countries along the "right" ideological path.

A further characteristic of the Soviet sixties that is represented in Read this and Travel is the proliferation of tourism. The tourism industry began to bourgeon in the 1960s, and the Soviet Union did not escape from the influence of this new form of leisure. ${ }^{62}$ The cartoon itself is advocating for an increase in tourism, something that would not have occurred in the strictly isolationist times of Stalin following the Second World War. ${ }^{63}$ Not only was tourism seen as a form of education and leisure at this time but it "also allowed ordinary people to engage in firsthand observation and even diplomacy."64

The concept of diplomacy through travel is clear throughout the cartoon, as the Soviet children make their way around the world spreading peace, love, and other morally positive "diplomatic" principles. The role of the Soviet youth as a tourist-ambassador, or acting as a role model, was a common perception as travel became more frequent. ${ }^{65}$ During the sixties, Soviet tourism was encouraged by a sense of exploration and education, but also of expansion and control. ${ }^{66}$ These ideals can be seen in the cartoon: the children are not only learning about the Western world, but are attempting to insert their own ideology into the lives of the people they meet. The transfer of ideologies is most clearly seen when the Soviet children travel to America. When encountering American children holding a racist and divisive 
book, the Soviet children take the opportunity to spread Soviet values by exchanging the American book for a Soviet one, espousing fraternal love and friendship. ${ }^{67}$ Throughout the cartoon, the insertion of Soviet values occur through the simplest of interactions - children meeting other children through leisure and travel.

This cartoon may also have connections to the global trend of world revolution in the 1960s, which corresponded with decolonization. The reference to countries in turmoil during the time of production, such as Japan, suggests the film encouraged global revolutionary movements. In the film, the children travel past Japan. ${ }^{68}$ The Japanese are shown as hard-working, a trait that the Soviet Union valued highly as representative of the ideal communist individual. ${ }^{69} \mathrm{~A}$ child is shown writing the word "mir" on a wall, which can be translated both into "peace" and "world." and the desire for peace by the child occur while a nearby volcano explodes in the background, creating an atmosphere of violence, chaos, and instability. ${ }^{71}$ The volcano can be reflective of the political atmosphere of Japan at the time. Protest in Japan was widespread during the late 1950s and reached a peak in $1960 .{ }^{72}$ These protests were connected to the US-Japan security treaty. ${ }^{73}$ At the time, many believed communism would prevail in Japan over the United States, a country resented because of post-war occupation. ${ }^{74}$ The scene of chaos in the cartoon may represent scenes of protest and revolution in Japan and other nonaligned countries while depicting the struggle as inclusive of youth and relevant to children watching. This encouragement of global revolution also aligns with the sixties spirit of competition for patronage of third-world societies. Both the Soviet Union and the United States were attempting to secure the patronage of decolonizing countries and, in the case of the Soviet Union, countries that showed frustration with negative aspects of American rule and capitalism.

The Three Fat Men is based on a story written by Yuri Olesha. Olesha is a more controversial figure than Mayakovsky, and the reasons behind the use of his short story as inspiration for a children's show are more ambiguous. Olesha's writing was banned during Stalin's lifetime as it was deemed too individualistic to be supportive of the Socialist state. ${ }^{75}$ However, Olesha was rehabilitated by the state with Khrushchev's ascendancy to power. As with Mayakovsky, it is possible that the use of Olesha's writing for a state-sanctioned production can be representative of a shift in the arts from a limited and restricted methodology towards a more open and accepting one.

The Three Fat Men is a story about the October Revolution, a coup d'état that saw the overthrow of the Provisional Government by the Lenin-led Bolshevik proletariats. The cartoon glorifies the Revolution as an event central to the Soviet Union's collective memory. The story underlines the interconnectedness between the event as a revolutionary movement and the global revolutions occurring in other jurisdictions during the sixties. As in the case of Japan, the sixties were a time of global unrest and decolonization, which led both the United States and the Soviet Union to compete for the patronage of other decolonizing countries. ${ }^{76}$ Still, there was a sense of competition in countries with firmly rooted ideologies. Globally, capitalist countries showed dissatisfaction with the prevalent ideology of the time. There was a sense that change was coming, and that this change may finally be in the form of a world-wide socialist revolution. There was also competition within the socialist system itself, as previously discussed in relation to the Sino-Soviet Split. The Three Fat Men was produced in 1963 and in mid-1962, Mao denounced the Soviet Union, calling it "revisionist" and "counter-revolutionary." "77 This deterioration of Sino-Soviet relations may have caused the Soviet Union to represent itself as a "true" socialist country compared to China. By glorifying the October Revolution, an event that in reality was not very romantic, the Soviet Union attempted to legitimize itself as a truly Soviet State, worthy of acting as China's "elder brother," as it had in the past. 
The Three Fat Men, through its glorification of revolution, bolsters many of the ideals represented in Read this and Travel. Read this and Travel depicted the Soviet Union as a role model for socialist countries through diplomatic tourism to the West and interaction with other Socialist countries. ${ }^{78}$ The Three Fat Man may have attempted to expand upon these ideals by turning to the Soviet history to legitimize this role. As the first socialist country, and a country founded through a glorious revolution as depicted in the two battles in the cartoon The Three Fat Men, the Soviet Union legitimizes its leadership role: a role which contested during the sixties through the Sino-Soviet Split. ${ }^{79}$ Furthermore, this is representative, once more, of the concept suggestively expressed in Read this and Travel of socialist internationalism. In this way, The Three Fat Men attempted to promote Sovietstyled socialist history to other socialist countries in another attempt to connect all socialist countries under one influence.

The underlying purpose and objective of these cartoons and their explicit narratives can tell historians many things, but they are often overlooked because they are seen as "[...] innocent of ideology and thus something that deals with the human rather than the political." ${ }^{\circ 0}$ From the two cartoons Read this and Travel and The Three Fat Men the viewer can see, subtly, several aspects of the era of the sixties: an increase in travel, awareness of world revolution, and competition both globally as a result of the Cold War and within the socialist system itself. These themes may have been imbedded intentionally as part of calculated propaganda, or unintentionally as symptomatic of the spirit of the 1960s. As a part of a larger propagandistic enterprise, these cartoons act as exemplars in examining how children would have learned about the system they were a part of and how the 1960s produced a unique sense of identity and awareness in the Soviet Union.

The two cartoons Read this and Travel and The Three Fat Men can tell the viewer much about the spirit of the sixties in the Soviet Union. Although many cartoons were produced during this period, these two animated children's films were chosen because of their striking similarities and their overt differences. Both cartoons can be representative of the struggle for patronage and hegemony that occurred throughout the 1960s, however The Three Fat Men focuses on the heroic past of the Soviet Union while Read this and Trave/ focuses on a bright, utopian future.

Furthermore, the policies of Khrushchev may have influenced the tone and texture of the sixties in the Soviet Union. Khrushchev's open policies permitted the advent of The Thaw, which helped many aspects of the sixties to come to fruition in the Soviet Union. Khrushchev also allowed for greater individuality and a unique brand of Soviet consumerism that helped facilitate the viewing of cartoons by individuals across the Soviet Union.

The two cartoons discussed may be interpreted as representative of several aspects of the Soviet sixties. These characteristics include the concept of socialist internationalism, competition and patronage both within and outside of the socialist system, and an increase in travel and tourism. These ideas both exist individually and in tandem. Because of an increase in travel, the concept of socialist internationalism came into force: individuals from socialist countries all over the globe could travel and visit the Soviet Union and spread socialist ideas. As seen in Read this and Travel, individuals from the Soviet Union were given the opportunity to travel to China and see a different brand of socialism, unique from the one they fashioned. Although the two animated features answer many questions concerning the atmosphere and aspect of the Soviet sixties, they beg the question concerning the true nature and quality of Soviet socialism during that time, as some questions cannot be answered by 'innocent' imagery on the television screen.

\section{ENDNOTES:}

1. Red Head, Read Head, Freckle Face (Рыжий Рыжий, Конопатый), directed by Leonid Nosyrev 
(1971; Moscow: Soyuzmultfilm).

2. Denis Kozlov and Eleonory Gilburd, "The Thaw as an Event in Russian History," in The Thaw: Soviet Society and Culture During the 1950s and 1960s, ed. Denis Kozlov and Eleonory Gilburd (Toronto: University of Toronto Press, 2013), 31.

3. Anne Gorsuch and Diane Koenker, "Introduction: The Socialist 1960s in Global Perspective," in The Socialist Sixties: Crossing Borders in the Second World, ed. Anne Gorsuch and Diane Koenker (Bloomington: Indiana University Press, 2013), 1, 6.

4. Natalie Kononenko, "The Politics of Innocence: Soviet and Post-Soviet Animation on Folklore topics," The Journal of American Folklore 124, no. 494 (2011): 273.

5. Brigit Beumers, "Comforting Creatures in Children's Cartoons," in Russian Children's Literature and Culture, ed. Marina Balina and Larissa Rudova (New York: Routledge, 2008), 154.

6. Kononenko, "The Politics of Innocence," 273.

7. Ibid., 275.

8. Laura Pontieri, Soviet Animation and The Thaw of the 1960s: Not Only for Children (New Barnet: John Libbey Publishing Ltd., 2012), 4.

9. Ibid., 85.

10. Ibid.

11. David MacFadyen, Yellow Crocodiles and Blue Oranges: Russian Animated Film since World War II (Canada: McGill-Queen's University Press, 2005), 87.

12. Pontieri, Soviet Animation and The Thaw, 4. 13. The phrase "thaw" was coined by the Soviet publicist llya Ehrenberg in 1954. The term, which was the title of Ehrenberg's novel, soon began to represent the spirit of liberalization many believed Khrushchev represented. See Kozlov and Gilburd, "The Thaw as an Event in Russian History," in The Thaw, 18.

14. Ibid., 29.

15. Sabina Mihelj, "The Politics of Privatization: Television Entertainment and the Yugoslav Sixties," in The Socialist Sixties: Crossing Borders in the Second World, ed. Anne Gorsuch and Diane Koenker (Bloomington: Indiana University Press, 2013), 252.
16. The meteorological metaphor of "The Thaw" has been extended to explain the cyclical nature of Khrushchev's liberalization policies. These cycles became known as successive "thaws" and "freezes." Khrushchev's policies were often uneven, allowing for unstable liberalization and reform, especially in arts and culture. As Kozlov and Gilburd have noted in the introduction to their collection, "Weather metaphors suggest instability and unpredictability." See Kozlov and Gilburd, "The Thaw as an Event in Russian History," in The Thaw, 21; Pontieri, Soviet Animation and the Thaw of the 1960s, 52.

17. Nikita Khrushchev, "Some Fundamental Questions of Present-Day International Development," in Documents of Modern Political

Thought, ed. Thomas E. Utley and Stuart Maclure (Cambridge: Cambridge University Press, 1957), 167.

18. Ibid.

19. Ibid., 168.

20. Ibid., 172.

21. Anne Gorsuch, "Time Travelers: Soviet Tourists to Eastern Europe," in Turizm: The Russian and East European Tourist Under Capitalism and Socialism, ed. Anne Gorsuch and Diane Koenker (New York: Cornell University Press, 2006), 205.

22. MacFadyen, Yellow Crocodiles and Blue Oranges, 143.

23. Ibid.

24. Kristin Roth-Ey, "Finding a Home for Television in the USSR, 1950-1970," Slavic Review 66, no. 2 (2007): 279.

25. Ibid., 281.

26. Gorsuch and Koenker, "Introduction," in The Socialist Sixties, ed. Gorsuch and Koenker, 11. 27. Kononenko, "The Politics of Innocence," 275. 28. Mihelj, "The Politics of Privatization," in The Socialist Sixties, ed. Gorsuch and Koenker, 352. 29. Kononenko, "The Politics of Innocence," 275. 30. Mihelj, "The Politics of Privatization," in The Socialist Sixties, ed. Gorsuch and Koenker, 253. 31. Roth-Ey, "Finding a Home for Television in the USSR," 282.

32. Ibid., 303.

33. Mihelj, "The Politics of Privatization," in The 
Socialist Sixties, 252.

34. Roth-Ey, "Finding a Home for Television in the USSR," 288.

35. MacFadyen, Yellow Crocodiles and Blue

Oranges, 105.

36. Ibid., 108.

37. Ibid., 124.

38. Ibid., 109.

39. Ibid., 108.

40. Ibid.

41. Pontieri, Soviet Animation and The Thaw, 41.

42. Ibid.

43. Ibid.

44. Ibid.

45. MacFadyen, Yellow Crocodiles and Blue

Oranges, 87; Pontieri, Soviet Animation and The Thaw, 84.

46. MacFadyen, Yellow Crocodiles and Blue Oranges, 87.

47. Thomas Lahusen, "Socialist Realism

(Soviet)," in Literature and Politics Today: The

Political Nature of Modern Fiction, Poetry, and

Drama, ed. M. Keith Booker (California: ABC-

CLIO, LLC, 2015), 302.

48. Ibid.

49. Ibid.

50. Derek Maus, "Mayakovsky, Vladimir (1893-

1930)," in Literature and Politics Today: The

Political Nature of Modern Fiction, Poetry, and

Drama, ed. M. Keith Booker (California: ABC-

CLIO, LLC, 2015), 200.

51. Ibid., 201.

52. Pontieri, Soviet Animation and The Thaw of the 1960s, 56.

53. Read this and Travel to Paris and China

(Прочти и Катай в Париж и Китай), directed

by Anatoly Karanovich and Teodor Bunimovich

(1960; Moscow: Soyuzmultfilm), 8:48.

54. Rachel Applebaum, "The Friendship Project:

Socialist Internationalism in the Soviet Union and Czechoslovakia in the 1950s and 1960s," Slavic Review 74, no. 3 (2015): 486.

55. Ibid.

56. Ibid., 485.

57. Read this and Travel to Paris and China

(Прочти и Катай в Париж и Китай), 7:45-7:59.

58. Ibid., 8:04.
59. Mingjiang Li, "Ideological dilemma: Mao's

China and the Sino Soviet Split," Cold War History

11, no. 3 (2011): 390.

60. Ibid., 391.

61. Applebaum, "Friendship Project," 485.

62. Gorsuch and Koenker, "Introduction," in The

Socialist Sixties, ed. Gorsuch and Koenker, 6.

63. Gorsuch, "Time Travelers," in Turizm, ed.

Gorsuch and Koenker, 205.

64. Gorsuch and Koenker, "Introduction," in The

Socialist Sixties, 15.

65. Ibid.

66. Gorsuch, "Time Travelers," in Turizm, ed.

Gorsuch and Koenker, 205.

67. Read this and Travel to Paris and China

(Прочти и Катай в Париж и Китай), 5:54-6:15.

68. Read this and Travel to Paris and China

(Прочти и Катай в Париж и Китай), 6:55-7:37.

69. Ibid., 7:27-7:59.

70. Ibid., 7:34-7:36.

71. Ibid., $7: 18$

72. William Marotti, "Political aesthetics: activism, everyday life, and art's object in 1960s' Japan," Inter-Asia Cultural Studies 7, no. 4 (2006): 606.

73. Ibid.

74. Ibid.

75. Victor Peppard, "Yuri (Karlovich) Olesha," in

Dictionary of Literary Biography: Russian Prose

Writers Between the World Wars, ed. Christine

Rydel, vol. 272 (Detroit: Gale, 2003). http://

go.galegroup.com.ezproxy.library.ubc.ca/ps/i.

\section{BIBLIOGRAPHY:}

\section{Filmography}

Brumberg, Valentina and Zinaida Brumberg, dir. The Three Fat Men (Три Толстяка). 1963; Moscow: Soyuzmultfilm.

Karanovich, Anatoly and Teodor Bunimovich, dir. Read this and Travel to Paris and China (Прочти и Катай в Париж и Китай). 1960; Moscow: Soyuzmultfilm.

Nosyrev, Leonid, dir. Рыжий Рыжий, Конопатый (Red Head, Read Head, Freckle Face). 1971; Moscow: Soyuzmultfilm. 


\section{Primary Sources}

Khrushchev, Nikita. "Some Fundamental Questions of Present-Day International Development." In Documents of Modern Political Thought, edited by Thomas E. Utley and Stuart Maclure, 166-173. Cambridge: Cambridge University Press, 1957.

\section{Secondary Sources}

Applebaum, Rachel. "The Friendship Project: Socialist Internationalism in the Soviet Union and Czechoslovakia in the 1950s and 1960s." Slavic Review 64, no. 3 (2015): 484-507.

Beumers, Brigit. "Comforting Creatures in Children's Cartoons." In Russian Children's Literature and Culture, edited by Marina Balina and Larissa Rudova, 153-171. New York: Routledge, 2008.

Gorsuch, Anne, and Diane Koenker. "Introduction: The Socialist 1960s in Global Perspective." In The Socialist Sixties: Crossing Borders in the Second World, edited by Anne Gorsuch and Diane Koenker, 1-21. Bloomington: Indiana University Press, 2013.

Gorsuch, Anne. "Time Travelers: Soviet Tourists to Eastern Europe." In Turizm: The Russian and East European Tourist Under Capitalism and Socialism, edited by Anne Gorsuch and Diane Koenker, 205-226. New York: Cornell University Press, 2006.

Kononenko, Natalie. "The Politics of Innocence: Soviet and Post-Soviet Animation on Folklore topics." The Journal of American Folklore 124, no. 494 (2011): 272-294.

Kozlov, Denis and Eleonory Gilburd. "The Thaw as an Event in Russian History." In The Thaw:
Soviet Society and Culture during the 1950s and 1960s, edited by Denis Kozlov and Eleonory Gilburd, 18-81. Toronto: University of Toronto Press, 2013.

Lahusen, Thomas. "Socialist Realism (Soviet)." In Literature and Politics Today: The Political Nature of Modern Fiction, Poetry, and Drama, edited by M. Keith Booker, 302311. California: ABC-CLIO, LLC, 2015.

Li, Mingjiang. "Ideological dilemma: Mao's China and the Sino-Soviet Split." Cold War History 11 , no. 3 (2011): 387-419.

MacFadyen, David. Yellow Crocodiles and Blue Oranges: Russian Animated Film since World War II. Canada: McGill-Queen's University Press, 2005.

Marotti, William. "Political aesthetics: activism, everyday life, and art's object in 1960s' Japan." Inter-Asia Cultural Studies 7, no. 4 (2006): 606-618.

Maus, Derek. "Mayakovsky, Vladimir (18931930)." In Literature and Politics Today: The Political Nature of Modern Fiction, Poetry, and Drama, edited by M. Keith Booker, 200-201. California: ABC-CLIO, LLC, 2015.

Mihelj, Sabina. "The Politics of Privatization: Television Entertainment and the Yugoslav Sixties." In The Socialist Sixties: Crossing Borders in the Second World, edited by Anne Gorsuch and Diane Koenker, 251267. Bloomington: Indiana University Press, 2013.

Peppard, Victor. "Yuri (Karlovich) Olesha." in Dictionary of Literary Biography: Russian Prose Writers Between the World Wars, edited by Christine Rydel, Vol. 272. Detroit: Gale, 2003. http://go.qalearoup.com. ezproxy.library.ubc.ca/ps/i. 